\title{
Environmental controls on the nitrogen-fixing cyanobacterium Nodularia spumigena in a temperate lagoon system in SE Australia
}

\author{
Daryl P. Holland ${ }^{1, *}$, Iris van Erp ${ }^{2}$, John Beardall ${ }^{1}$, Perran L. M. Cook ${ }^{3}$ \\ ${ }^{1}$ School of Biological Sciences, Monash University, 3800 Clayton, Victoria, Australia \\ ${ }^{2}$ Department of Environmental Sciences, Aquatic Ecology and Water Quality Management Group, Wageningen University, \\ PO Box 47, 6700 AA Wageningen, The Netherlands \\ ${ }^{3}$ Water Studies Centre, Monash University, 3800 Clayton, Victoria, Australia
}

\begin{abstract}
Estuarine blooms of $\mathrm{N}_{2}$-fixing cyanobacteria are rare, and the factors controlling them remain poorly understood outside the Baltic Sea. We measured in situ physico-chemical conditions and undertook nutrient-addition bioassays and dilution-based grazing experiments fortnightly over the 2010 to 2011 Austral spring-summer-autumn, to evaluate the role of physical environmental drivers, grazing and macronutrients on the growth of Nodularia spumigena Mertens (hereafter Nodularia) in a temperate lagoon system (Gippsland Lakes, Australia). Nodularia appeared in late summer, following a period of warm weather (water temperature $>22^{\circ} \mathrm{C}$ ), high solar exposure, calm conditions, relatively low salinity $(<22)$ and low dissolved inorganic nitrogen $\left(\sim 0.4 \mu \mathrm{mol} \mathrm{l}{ }^{-1}\right)$. A major bloom did not eventuate. Bioassays indicated $\mathrm{N}$ limitation prior to Nodularia appearing, and $\mathrm{P}$ limitation after, while in situ nutrient concentrations indicated $\mathrm{N}$ limitation throughout. Nodularia grew rapidly $\left(\sim 0.4 \mathrm{~d}^{-1}\right)$ in control bioassays (no nutrients added), whereas other phytoplankton taxa showed zero or negative growth. $\mathrm{N}$ addition caused significantly lower Nodularia growth, while other taxa had higher growth. P addition did not significantly enhance Nodularia growth. This suggests Nodularia was able to obtain P from the water column and from phytoplankton breakdown. A reduction in grazing pressure via dilution led to lower growth rates of Nodularia and higher growth rates of other phytoplankton taxa. This suggests that the grazers selectively consumed taxa other than Nodularia, and that grazing positively influences Nodularia growth in this system. These data indicate that Nodularia growth was limited in situ by physical conditions (primarily solar radiation) and that nutrients and grazing were of second order importance.
\end{abstract}

KEY WORDS: Nodularia spumigena $\cdot$ Nutrient limitation $\cdot$ Grazing $\cdot$ Bioassay

\section{INTRODUCTION}

Phytoplankton biomass in many temperate estuaries is frequently considered to be $\mathrm{N}$ limited due to low ratios of dissolved inorganic nitrogen (DIN) to dissolved inorganic phosphorus (DIP) concentrations relative to the requirements of these elements by phytoplankton (Howarth \& Marino 2006). N limitation should favour the proliferation of organisms capable of fixing atmospheric nitrogen $\left(\mathrm{N}_{2}\right)$, such as the cyanobacterial family Nostocaceae (which includes the common bloom forming genera Anabaena, Aphanizomenon, Cylindrospermopsis and Nodularia), yet these organisms occur in relatively few estuaries (Howarth et al. 1988, Sellner 1997). Nodularia spumigena (hereafter Nodularia) is the most common $\mathrm{N}_{2}$-fixing species found in brackish waters. It frequently blooms in the Baltic Sea and linked 
estuarine systems (Stal et al. 2003), and has also caused blooms in several Australian estuaries, including the Peel-Harvey system in south western Australia (McComb \& Humphries 1992), the lower lakes of the Murray River (Codd et al. 1994), Orielton Lagoon in Tasmania (Jones et al. 1994) and in the Gippsland Lakes, SE Australia (Webster et al. 2001, Cook \& Holland 2012), the focus of this study.

There are contradictory reports on the effects of grazing on $\mathrm{N}_{2}$-fixing cyanobacteria in estuaries. In a series of mesocosm experiments in which grazers and nutrients were manipulated, Chan et al. (2006) found that the relative abundance of heterocystous cyanobacteria is suppressed by grazers, although the total phytoplankton biomass is not affected. This implies that the heterocystous cyanobacteria (in that study, Anabaena sp.) were either being preferentially grazed or were less able to cope with grazing than were the competing phytoplankton taxa. Grazing reduced both the biomass of filamentous cyanobacteria and the average filament size, often to below the threshold that allows heterocysts to develop, thus removing the advantage of $\mathrm{N}_{2}$ fixation (Marino et al. 2002). However, evidence suggests that grazing pressure can facilitate cyanobacterial dominance through selective grazing. The presence of copepods, for example, enhances the growth of Nodularia when this organism is incubated with a natural phytoplankton assemblage, but not when incubated alone (Gorokhova \& Engstrom-Ost 2009). There is also evidence that copepods can lower the ratio of DIN:DIP in the water column and thus favour $\mathrm{N}_{2}$-fixing cyanobacteria (Hambright et al. 2007). In general, cyanobacteria are considered to be a poor food source for most zooplankton (Boon et al. 1994).

Other factors postulated to control cyanobacterial blooms in estuaries include high salinity (Marino et al. 2006) and viruses (Pollard \& Young 2010). Suboptimal growing conditions, such as low insolation or persistent watercolumn mixing may prevent a bloom forming or reduce its size or longevity (Paerl 1990, Moisander et al. 2002).

To date, the majority of studies on the environmental controls on heterocystous cyanobacteria in estuaries have been undertaken in culture and in artificial mesocosm studies; studies where cultured, non-native cyanobacteria and/or grazers are introduced to natural populations of estuarine phytoplankton. In this study, we set out to test the effect of grazers and nutrients on the growth potential of Nodularia and other phytoplankton over a 6 mo growing season, using dilution experiments and nutrient addition bioassays on natural populations taken directly from a temperate lagoon system that suffers from recurring blooms of Nodularia (Gippsland Lakes, Australia). We set out to test the following hypotheses: (1) The potential growth of Nodularia in the Gippsland Lakes is P limited under otherwise ideal growth conditions, while the growth of other phytoplankton taxa is $\mathrm{N}$ limited, and (2) Grazing has little effect on the growth of Nodularia in the Gippsland Lakes. We complemented the experimental results with observations of weather and in situ physico-chemical conditions in the lakes.

\section{MATERIALS AND METHODS}

\section{Site description}

The Gippsland Lakes is a system of large, shallow coastal lagoons occupying $354 \mathrm{~km}^{2}$ in temperate SE Australia (Fig. 1). The Gippsland Lakes contain a population of Nodularia which blooms at an unusually high salinity, 9 to 20 (Cook \& Holland 2012) and grows well at salinities of at least 25 (Myers et al. 2010). Summer Nodularia blooms occurred sporadically (at 1 to $3 \mathrm{yr}$ intervals) in the Gippsland Lakes between 1988 and 2002 (Cook \& Holland 2012), but between 2003 and the start of 2011 there was no bloom. This lack of bloom formation is attributed to a persistent drought and resultant high salinity and low nutrient inputs. The only large inflows in this

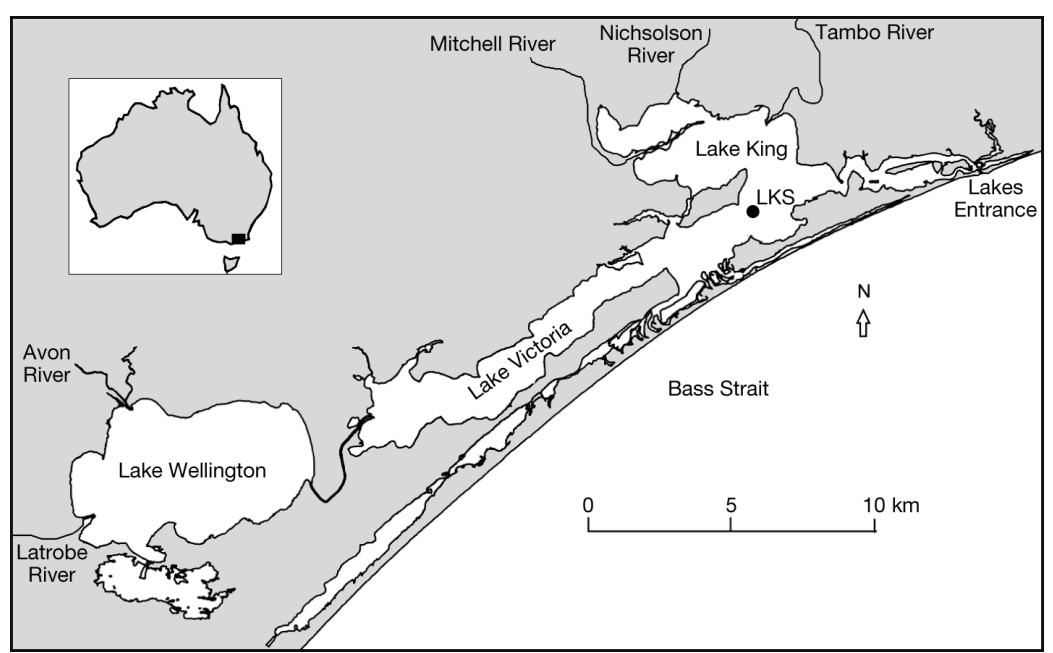

Fig. 1. The Gippsland Lakes, showing the sampling site LKS, the 3 main lakes, 5 main rivers and the permanent entrance at Lakes Entrance. The inset shows its location within Australia 
period led to major flooding in 2007 following a catchment-wide wildfire, and this brought an unprecedented load of $\mathrm{N}$ into the system and led to a lakewide bloom of Synechococcus sp. (Cook \& Holland 2012). Based on an observational study (Cook \& Holland 2012), we hypothesised the minimum and maximum environmental conditions that occur prior to a Nodularia bloom. These conditions were water temperature $(T)>20^{\circ} \mathrm{C}$, salinity (S) between 9 and 20 , surface DIN:FRP $<5$ (FRP = filterable reactive phosphorus) and DIN $<0.4 \mu \mathrm{mol} \mathrm{l}^{-1}$.

Beginning in the winter of 2010, a strong La Niña event in the Pacific Ocean, coupled with a strongly negative Indian Ocean Dipole, led to widespread and persistent rainfall over eastern Australia. The Gippsland Lakes received large inflows in late August 2010, followed by regular rainfall events throughout the spring and following summer.

The sampling site (LKS) is located in the southern part of Lake King (Fig. 1), and has been monitored for more than 30 yr (Site 002314 on the Victorian Water Resources Data Warehouse, www.vicwaterdata.net). LKS is a site commonly associated with Nodularia blooms.

\section{Sampling}

The lakes were visited fortnightly between September 2010 and April 2011. Surface water for bioassays and grazing experiments was collected in $20 \mathrm{l}$ carboys from site LKS (Fig. 1). Water samples for DIN and FRP analysis were filtered through $0.45 \mu \mathrm{m}$ syringe filters. All samples were stored on ice and returned to Monash University on the day of sampling, where they were frozen until analysis. Nutrient concentrations were measured in a NATA (National Association of Testing Authorities) accredited analytical laboratory using standard techniques. We also conducted water column profiles of $\mathrm{S}$ and $T$ and measured the Secchi depth.

Zooplankton was collected from February onwards; 51 lake water samples were collected in Niskin Bottles at $1 \mathrm{~m}$ intervals, passed through a $67 \mu \mathrm{m}$ mesh and the contents of the mesh were rinsed into $150 \mathrm{ml}$ Nalgene PETG bottles and preserved with Lugol's iodine.

Additionally, wind speed and solar exposure at Bairnsdale airport ( $20 \mathrm{~km} \mathrm{NE}$ of the study site) was obtained from the Australian Bureau of Meteorology (www.bom.gov.au), and river flow data was obtained from the Victorian Water Resources Data Warehouse (www.vicwaterdata.net).

\section{Chlorophyll a fluorescence}

Chlorophyll a (chl a) was used as a proxy for biomass, and was measured using a non-destructive fluorometric technique (Jakob et al. 2005), in a Phytopam Phytoplankton Analyzer (Heinz Walz) connected to a PC running PhytoWIN software. This device allows the fluorescence output to be deconvoluted into 3 channels, representing the major phytoplankton groups: green (chlorophytes), brown (diatoms and dinoflagellates) and cyan (cyanobacteria). The default reference spectra were used.

The total chl a calculated by the Phytopam was calibrated against samples filtered for extractible chl $a$. Representative samples were filtered onto Whatman GF/F filters at the start and end of each experiment, and the chl a was extracted in $90 \%$ acetone and analysed spectrophotometrically (Lorenzen 1967). Additionally, the output of the cyan channel was compared with direct microscopic measurements of Nodularia biomass.

\section{Bioassays and grazing experiments}

Nutrient additions were $100 \mu \mathrm{M}$ ammonium (N) and $10 \mu \mathrm{M}$ phosphate $(\mathrm{P})$. These additions were of a similar magnitude to the additions used in another bioassay study (Peeters \& Peperzak 1990). Four different bioassay treatments were used: $\mathrm{C}$ (control), $\mathrm{N}$ (N added), P (P added) and NP (both N and P added).

For the grazing experiments (Landry \& Hassett 1982), unfiltered lake water was diluted with lake water filtered through Whatman GF/F filters to concentrations of $5 \%$ and $20 \%$. C and NP treatments were prepared for each dilution. The grazing rate was calculated from a linear line of best fit (using least sum of squares) through plots of dilution versus measured growth rate, assuming a linear reduction in grazing pressure with dilution. The phytoplankton growth rate in the absence of grazers was the intercept of this line.

Triplicate $100 \mathrm{ml}$ samples for each treatment were prepared in $150 \mathrm{ml}$ Nalgene PETG bottles. For statistical purposes, we considered the $20 \mathrm{l}$ carboy to be the 'site', and the incubation bottles were experimental units taken from this 'site'. Bottles were incubated in a temperature-controlled water bath at ambient site $T \pm 1^{\circ} \mathrm{C}$, under an ambient light:dark cycle (adjusted for the time of year) and illumination of approximately $100 \mu \mathrm{mol}$ photons $\mathrm{m}^{-2} \mathrm{~s}^{-1}$. Chl a fluorescence was measured every 1 to $3 \mathrm{~d}$ using the Phytopam. 
Growth was followed for between 7 and $13 \mathrm{~d}$. In most cases, total chl a was in decline by the end of the experiment, so max. chl a was used as a measure of growth potential rather than final chl $a$.

Nutrient limitation was determined using a lntransformed response ratio (lnRR) for each treatment (Goldberg et al. 1999), where

$$
\ln R R=\ln (\mathrm{T} / \mathrm{C})
$$

$\mathrm{T}$ is the max. chlorophyll in the treatment bioassay and $\mathrm{C}$ is the max. chl $\mathrm{a}$ in the control.

The major zooplankton and phytoplankton taxa were identified in a Sedgwick rafter cell at 100× magnification. The major grazers, copepods, copepod nauplii and mussel larvae were enumerated. Nodularia biomass was calculated from several samples.

\section{Statistics}

Based on our knowledge of the system and the competitive relationships between, and the nutrient requirements of, the phytoplankton groups involved, we formulated the following hypotheses, which were individually tested: (1) P addition gave significantly higher Nodularia growth compared to control, (2) N addition gave significantly lower Nodularia growth compared to control, (3) N and P addition gave significantly higher Nodularia growth compared to control, (4) P addition had no significant effect on growth of the diatom/dinoflagellate group compared to the control, (5) N addition gave significantly higher diatom/dinoflagellate growth compared to control, and (6) $\mathrm{N}$ and $\mathrm{P}$ addition gave significantly higher diatom/dinoflagellate growth compared to control.

The test involved 2-way factorial ANOVAs comparing each of the nutrient additions against the controls with trip number as the second factor. The time factor was restricted to the period from 2 February 2011, when Nodularia was present in lake samples, until the end of the study. We hypothesised that time would have no significant effect on any of the comparisons. The significance level was set at $\mathrm{p}<0.05$.

\section{RESULTS}

\section{Phytoplankton}

Diatoms dominated the water column throughout the monitoring period. The most abundant genera were Chaetoceros and Ditylum. Less abundant genera included the diatoms Melosira, Skeletonema,
Pseudo-nitzschia, Nitzschia, Coscinodiscus, Gyrosigma and Navicula, as well as the dinoflagellate genera Prorocentrum, Ceratium and Protoperidinium. Nodularia filaments were not observed in any samples until 2 February, after which they were present in low numbers through to the end of the sampling period. The chl $a$ in the lake samples that was-prior to incubation - associated with Nodularia never exceeded $3 \%$ of the total chl a.

\section{Zooplankton}

The in-lake zooplankton community was quantified on 2 occasions, 16 February and 3 March 2011. The zooplankton was dominated by copepods, copepod nauplii and mussel larvae. Rotifers were also common, but these were not enumerated. No cladocerans were identified in any sample. Copepod abundance in the surface water varied from 5000 to 11000 ind. $\mathrm{m}^{-3}$, nauplii ranged from 40000 to 100000 ind. $\mathrm{m}^{-3}$ and mussel larvae from 130000 to 360000 ind. $\mathrm{m}^{-3}$.

\section{Nodularia bloom conditions}

The nutrient concentrations, $T$ and $\mathrm{S}$ are reported with reference to the hypothesised min. and max. conditions that occur prior to a Nodularia bloom, based on a previous observational study at the same site (Cook \& Holland 2012). These conditions are water $T>20^{\circ} \mathrm{C}$, S between 9 and 20 , surface DIN:FRP $<5$ and DIN $<0.4 \mu \mathrm{mol} \mathrm{l^{-1 }}$.

Ideal bloom conditions occurred at the end of January, when $T$ was $24^{\circ} \mathrm{C}, \mathrm{S}$ was at, or perhaps slightly above 20, DIN:FRP was $<1$ and DIN dropped to $\sim 0.4 \mathrm{mmol} \mathrm{l}^{-1}$ (Fig. 2). This coincided with a prolonged period of calm in the second half of January when the $7 \mathrm{~d}$ average max. wind speed was always $<40 \mathrm{~km} \mathrm{~h}^{-1}$ (Fig. 2D), and a sustained period of high solar exposure (>20 MJ m${ }^{-2}$ ) (Fig. 2C). After this period of calm, there were frequent periods of high wind during February $\left(>65 \mathrm{~km} \mathrm{~h}^{-1}\right.$ ) and the $7 \mathrm{~d}$ average max. wind speed exceeded $45 \mathrm{~km} \mathrm{~h}^{-1}$. Solar exposure dropped to $<10 \mathrm{MJ} \mathrm{m}^{-2}$ on 5 February, after which it was highly variable but did not return to the levels seen in late January (Fig. 2C). Secchi depth in the water varied between 1.7 and $3.1 \mathrm{~m}$, apart from the first sampling trip, where high turbidity associated with high inflows reduced it to $0.3 \mathrm{~m}$. Solar exposure at the surface, therefore, was considered a reasonable relative measure of solar exposure to the phytoplankton. 

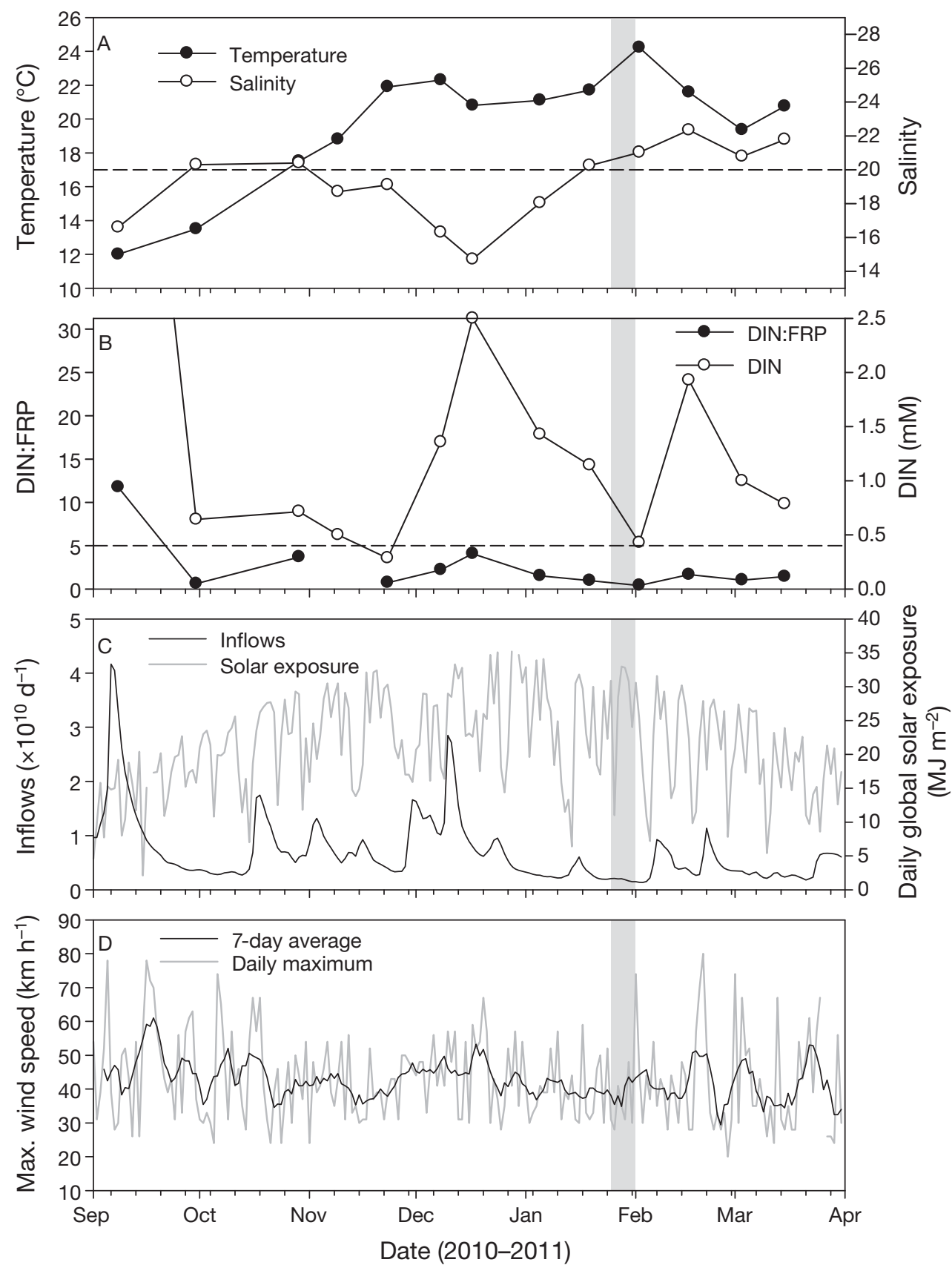

Fig. 2. Physico-chemical conditions in the Gippsland Lakes during the study period. Grey bars represent the critical period just before the appearance of Nodularia spumigena in the lakes. (A) Surface water temperature (T) and salinity (S) at site LKS. Dashed line represents the hypothesised $\min . T\left(17^{\circ} \mathrm{C}\right)$ and max. S $(20)$ required before a Nodularia bloom will occur $(\mathrm{Cook} \&$ Holland 2012). (B) Dissolved inorganic nitrogen (DIN) and the ratio of DIN:FRP (FRP = filterable reactive phosphorus) in the surface water of LKS. Dashed line represents the hypothesised max. DIN:FRP ratio (5) and DIN $\left(0.4 \mu \mathrm{mol} \mathrm{l}^{-1}\right)$ required before a Nodularia bloom will occur (Cook \& Holland 2012). DIN:FRP ratio for 11 November 2010 was omitted because FRP at that time was undetectable and therefore the ratio could not be calculated. (C) Daily inflows into the Gippsland Lakes and daily global solar exposure at nearby Bairnsdale Airport. (D) Max. wind speed and $7 \mathrm{~d}$ average max. wind speed at Bairnsdale Airport

Nodularia was observed in bioassays taken from 2 February onwards and numbers reached bloom proportions (defined as biovolume $>0.2 \mathrm{~mm}^{3} \mathrm{l}^{-1}$ ) in Lake King on 22 February 2011. This was a significant event, as Nodularia had not been seen above trace levels for the 9 previous yr. A large bloom did not, however, eventuate, with a max. biovolume of $0.79 \mathrm{~mm}^{3} \mathrm{l}^{-1}$ reported by EPA Victoria (C. Garland pers. comm.). 


\section{Bioassays}

The addition of $\mathrm{N}$ alone led to enhanced phytoplankton growth in 10 of the 13 bioassays, while $\mathrm{P}$ additions led to growth indistinguishable from that in the control in all bioassays until February, after which growth was enhanced in all further bioassays (Fig. 3). The NP treatments led to the highest biomass on all occasions, apart from 2 February, when it was equal to that in the $\mathrm{N}$ treatment (Fig. 3). These results suggest that the phytoplankton were $\mathrm{N}$ limited or $\mathrm{N}$ and $\mathrm{P}$ co-limited at all times up until 2 February, after which the limiting nutrient was less obvious. On 2 February and 3 March, growth was enhanced independently by the addition of either P or N. On 16 February and 15 March, growth was P limited.

The response rate to nutrient treatments was consistent with what would be predicted from the in situ surface DIN:FRP ratio up until February, after which the response to nutrient addition became partially decoupled from in-lake $\mathrm{N}$ concentration (compare Fig. 2 and Fig. 3).

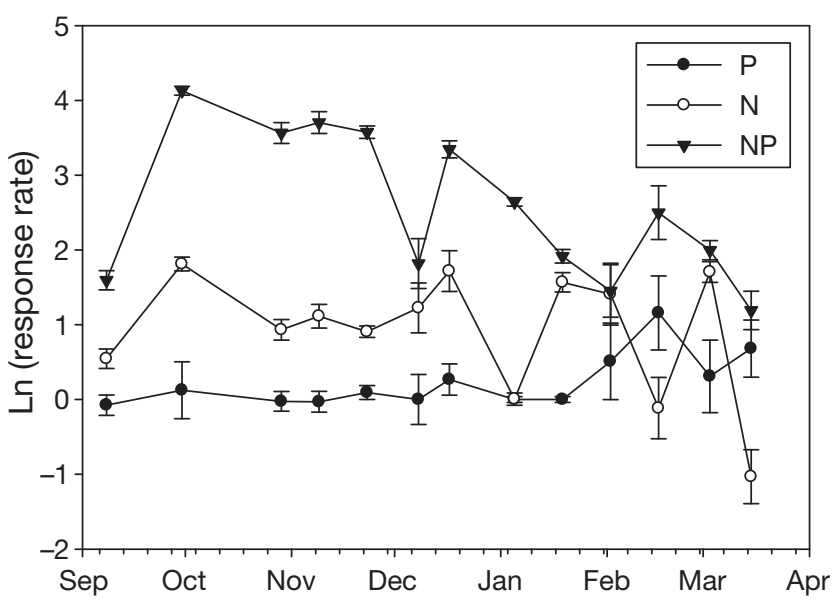

Fig. 3. Response rate of nutrient treatments on the max. chlorophyll a $(\mathrm{chl}$ a) reached in each bioassay. Error bars: $\pm \mathrm{SE}$
From February onwards, the cyanobacteria were primarily Nodularia, and the cyan channel of the Phytopam was well correlated with the measured Nodularia biomass $\left(\mathrm{R}^{2}=0.83\right)$. Nodularia grew consistently well in both the control and NP samples, but showed a variable response to $\mathrm{N}$ or $\mathrm{P}$ addition. The highest Nodularia biovolume measured in the bioassays was $\sim 46 \pm 24 \mathrm{~mm}^{3} \mathrm{l}^{-1}$ and was found in the control treatment incubated from 15 March, when, after $13 \mathrm{~d}$ incubation under idealised growth conditions, Nodularia made up over $90 \%$ of the total phytoplankton biomass. Compared to the control treatments, N addition induced a lower growth rate of Nodularia in 3 out of the 4 bioassays, and $\mathrm{P}$ addition led to a lower growth rate in half of the bioassays (Fig. 4).

For Nodularia, there was a significant difference between the control and $\mathrm{N}$ treatments $(F=4.714, \mathrm{p}=$ 0.045), but not between the control and $P$ treatments $(F=0.869, \mathrm{p}=0.365)$ or the control and NP treatments $(F=3.252, \mathrm{p}=0.090)$. This suggests that $\mathrm{N}$ was, overall, favouring other algal species at the expense of Nodularia, whereas $\mathrm{P}$ had little effect. Trip number had no significant effect in any Nodularia test, and there were no significant interactions between trip and treatment. In the control treatments, the growth of Nodularia appeared to be at the expense of other algae (Fig. 4). Growth of the diatom and dinoflagellate population (brown channel of the Phytopam) was significantly higher than the control treatments in the NP treatment $(F=5.552, \mathrm{p}=0.008)$ and in the N treatment $(F=6.567, \mathrm{p}=0.004)$, but there was no significant difference between the control and $\mathrm{P}$ treatment $(F=2.657, \mathrm{p}=0.145)$. There was a significant effect of trip number when control and NP $(F=19.987, \mathrm{p}<$ $0.001)$ and control and $\mathrm{N}$ were compared $(F=9.299$, $\mathrm{p}=0.008$ ), and there was a significant interaction between trip and treatment for the control versus NP $(F=4.312, \mathrm{p}=0.021)$ and control versus $\mathrm{P}(F=3.727$, $\mathrm{p}=0.033)$ comparisons.

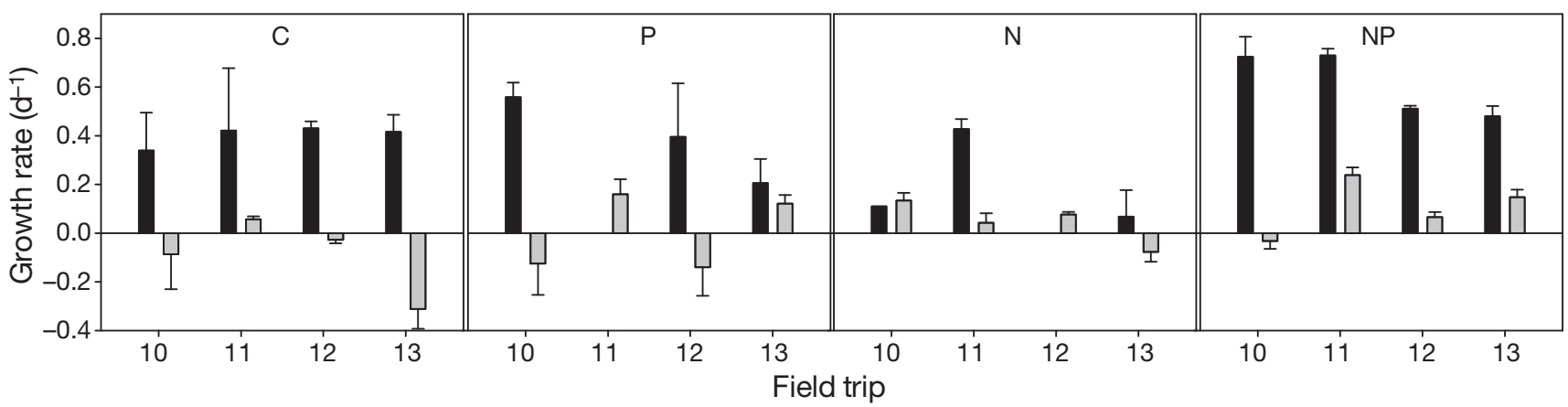

Fig. 4. Growth rates of Nodularia spumigena (black bars) and diatoms plus dinoflagellates (grey bars) during bioassay incubations for Sampling Trips 10 to 13 (2 February to 15 March). C = control treatments, $\mathrm{N}=$ nitrogen addition, $\mathrm{P}=$ phosphorus addition, $\mathrm{NP}=$ nitrogen and phosphorus addition. Error bars: $\pm \mathrm{SE}$ 


\section{Grazing}

In the control treatments, the grazing rate of the phytoplankton as a whole was approximately equal to the phytoplankton growth rate (in the absence of grazers), indicating that the system was in equilibrium (Fig. 5A). The addition of $\mathrm{N}$ and $\mathrm{P}$ led to enhanced phytoplankton growth rate and grazing rates, but the phytoplankton growth was always higher than the grazing rate, and the phytoplankton biomass therefore increased (Fig. 5B).

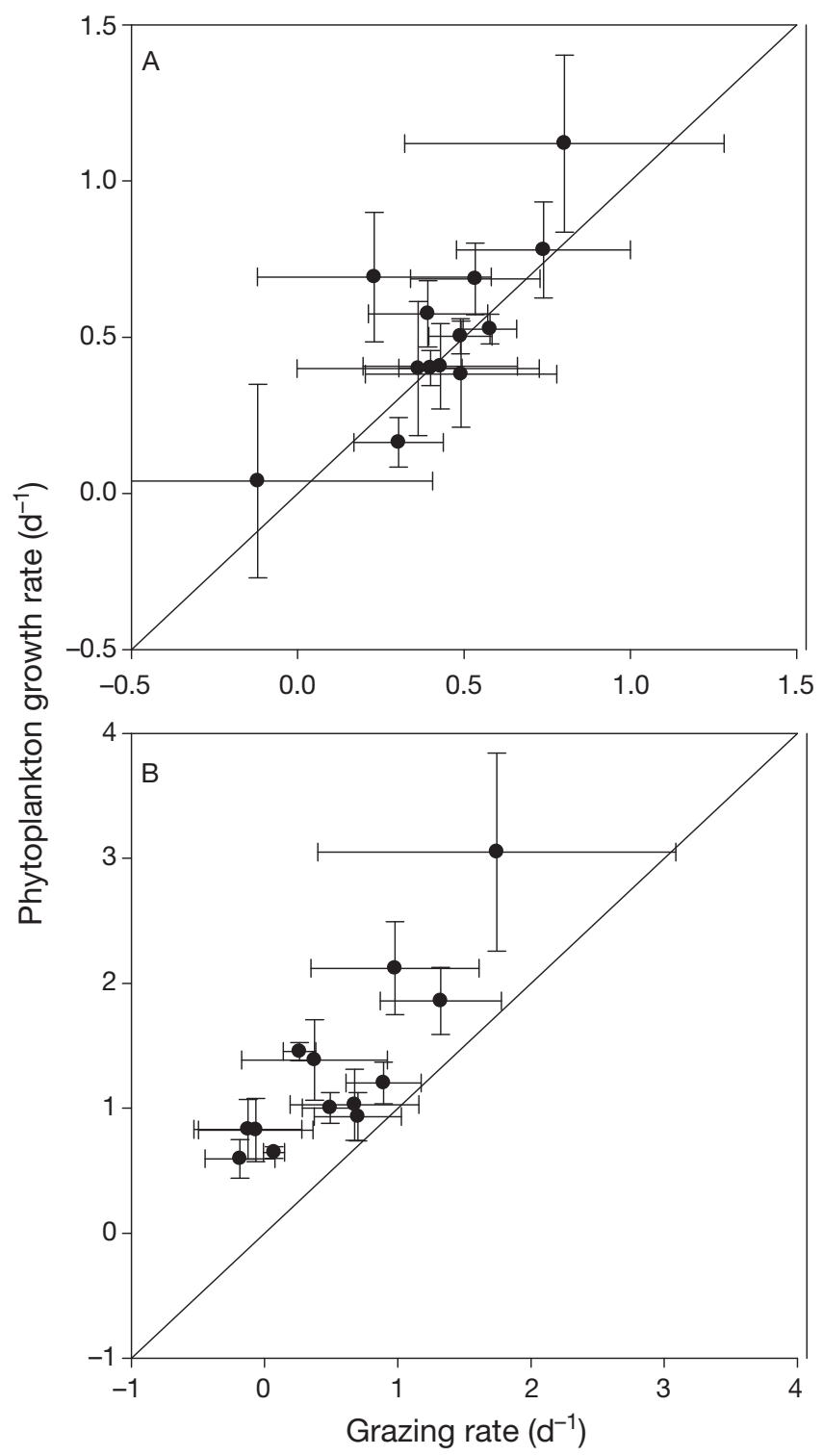

Fig. 5. Phytoplankton growth rate (in the absence of grazers) plotted against the grazing rate. (A) Control treatment, (B) added $\mathrm{N}$ and $\mathrm{P}$. The line represents 1:1, where the population growth rate is equal to the grazing rate, i.e. no net change in biomass. Error bars: $\pm \mathrm{SE}$
Grazing 'rates' of Nodularia, however, were unusual in that the Nodularia showed the highest growth rates in the undiluted samples, i.e. when the grazing pressure was the highest. This equates to a negative grazing rate, which implies enhanced growth in the presence of grazers. Contrast this with the other dominant phytoplankton (diatoms and dinoflagellates), which showed a classic dilution response, wherein the highest dilutions and therefore the lowest grazing pressure induced the highest growth rates (Fig. 6).

\section{DISCUSSION}

Blooms of $\mathrm{N}_{2}$-fixing cyanobacteria in estuaries are rare and often unpredictable, and this complicates experimental and observational studies using in situ populations. To date, most experiments on the factors controlling the growth of heterocystous cyanobacteria in estuaries have been undertaken in culture, long term mesocosm or inoculation studies (e.g. Panosso \& Graneli 2000, Chan et al. 2006, Gorokhova \& Engstrom-Ost 2009), with a few notable exceptions (e.g. Twomey \& Thompson 2001, Moisander et al. 2003). While these studies have provided critical pioneering insights, there is a dearth of studies on natural populations and the factors controlling their growth over time. To our knowledge, this is the first study to undertake repeated short-term bioassay experiments combined with in situ observations to investigate the factors controlling the growth of heterocystous cyanobacteria in an estuary.

\section{Environmental factors in situ}

We have previously identified the key indicators of the risk of a Nodularia bloom in the Gippsland Lakes to be DIN concentrations $<0.4 \mu \mathrm{mol} \mathrm{l}^{-1}$ and $\mathrm{S}<20$ during the summer months (Cook \& Holland 2012). These conditions typically occur after a wet spring. S remained close to 20 throughout the summer of 2010 to 2011. DIN, however, remained elevated throughout December owing to sustained elevated inflows (Fig. 2). Inflows were low in January, and the DIN concentration fell to a min. of $\sim 0.4 \mu \mathrm{M}$ at the start of February, and it was at this point that Nodularia was first observed. Nodularia persisted in relatively low concentrations throughout February and into March 2011. In some systems, dissolved $\mathrm{N}$ and reactive $\mathrm{P}$ ratios are poor indicators of nutrient limitation, and the total $\mathrm{N}$ and $\mathrm{P}$ levels are more appropriate (Dodds 

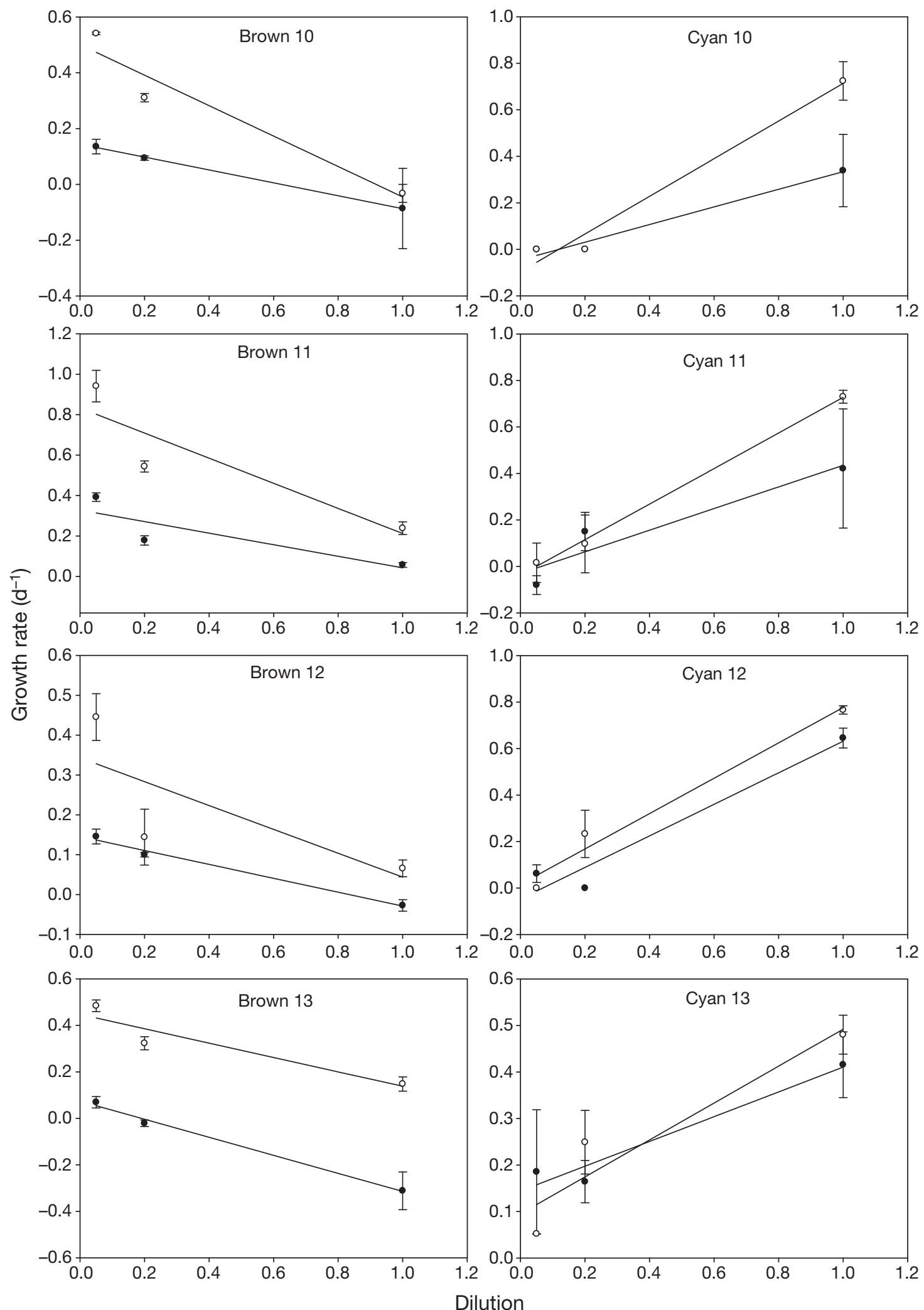

Fig. 6. Growth rate of Nodularia spumigena (right column, labelled 'cyan') and diatoms plus dinoflagellates (left column, labelled 'brown') after dilution to reduce grazing pressure. Typical dilution experiments follow the trends on the right, where growth is enhanced by a reduction in grazers. Closed symbols represent the control treatment, and open symbols represent the treatment with added P and N. Error bars: \pm SE 
2003). Our previous work suggests, however, that in this lake system the dissolved nutrient levels and the DIN:FRP ratio are superior to TN:TP at predicting nutrient limitation (Cook \& Holland 2012).

We were able to induce rapid growth of Nodularia in the control bioassays $\left(\sim 0.4 \mathrm{~d}^{-1}\right)$, which were incubated in a stable, well-lit environment. The potential for a bloom therefore existed, but it did not eventuate in the field. In addition to physico-chemical conditions within the permissive Nodularia window (see above), the weather conditions for bloom initiation were ideal in late January, when average wind speeds were consistently low and solar exposure and temperatures were consistently high (Jöhnk et al. 2008). It was immediately after these conditions that Nodularia first appeared. Thereafter, wind speed increased, leading to a greater mixing of the water column (Fig. 2), and solar exposure became more variable. Increased wind, in particular, is likely to have a negative effect on Nodularia, because it counteracts its ability to control buoyancy and thus gain a competitive advantage over other taxa (Reynolds \& Walsby 1975, Paerl 1990). Increased shear at higher wind speeds may also have reduced Nodularia growth rates (Moisander et al. 2002).

Another critical factor that reduced the viability of Nodularia was that DIN concentrations increased in February (Fig. 2), probably due to a combination of the aforementioned water column mixing plus increased river flows. This also reduced Nodularia's other competitive advantage, the ability to fix atmospheric $\mathrm{N}_{2}$ (Horne \& Galat 1985). Under more $\mathrm{N}$ replete conditions, smaller and relatively fast growing phytoplankton (in this case diatoms and dinoflagellates) outcompete Nodularia. High nitrate also induces the formation of akinetes (resting cells) in Nodularia (Myers et al. 2011). Further support for this argument comes from the bioassays, where Nodularia did not grow following the addition of $\mathrm{N}$ alone in 3 out of the 4 bioassays that had Nodularia present (see next section).

\section{Macronutrients}

The waters of Lake King had a very low DIN:FRP ratio $(<5)$ throughout the summer of 2010 to 2011, indicating $\mathrm{N}$ limitation. Prior to February, the bioassays and the in situ nutrient concentrations agreed with the putative limiting nutrient $(\mathrm{N})$, with the exception of 5 January 2011, where the bioassays suggested $\mathrm{N}$ and P co-limitation (Fig. 2). When Nodularia appeared, however, the situation changed.
Samples collected on 16 February and 15 March 2011 were clearly not $\mathrm{N}$ limited in the bioassays (Fig. 3), even though DIN:FRP ratio was <1 (Fig. 2). The phytoplankton $\mathrm{N}$ requirements must, therefore, have been met by the fixation of $\mathrm{N}_{2}$ by Nodularia.

Given that Nodularia was not $\mathrm{N}$ limited, it might be assumed that it was therefore P limited, and the addition of P would stimulate Nodularia growth. This was not the case, as there was no significant difference in the growth of Nodularia between the control and P treatments. We have 2 explanations for this. (1) FRP concentrations in the water column were high throughout the summer $\left(\sim 1 \mu \mathrm{mol} \mathrm{l}{ }^{-1}\right)$, and (2) Nodularia may have been scavenging $\mathrm{P}$ from other phytoplankton species as those populations declined (Fig. 4), and therefore had no need for additional P.

The addition of $\mathrm{N}$ alone tended to favour other algal species at the expense of Nodularia, compared to the control treatment. A similar result was seen in the bioassay experiments of Marcarelli et al. (2006), where Nodularia growth was lower after $\mathrm{N}$ addition. The addition of both $\mathrm{N}$ and $\mathrm{P}$ on the other hand resulted in no significant difference in Nodularia growth compared to the control treatment. On this basis, we suggest that the most likely mechanism for reduced rates of Nodularia growth in the $\mathrm{N}$ treatment was P competition, with other phytoplankton taxa showing significantly higher growth rates (or reduced rates of decline) in the $\mathrm{N}$ treatment compared to the control.

\section{Grazing}

Grazing pressure enhanced the competitive ability of Nodularia. In our experiments, grazers were able to suppress the growth of the total phytoplankton population and, in particular, the dominant diatom and dinoflagellate population, whereas Nodularia proliferated. The most likely explanation for this is that the grazers were preferentially consuming the diatoms and dinoflagellates, and therefore giving the Nodularia a competitive advantage. If the grazers were removed, then the diatoms and dinoflagellates were able to outcompete the Nodularia.

Mussel and copepod larvae were the dominant grazers when Nodularia was present. Nodularia filaments are too large to be consumed by mussel larvae (Widdows 1991), and even if the larvae could consume Nodularia, it would be a poor quality food, as it lacks long-chain fatty acids, which are essential to the diets of these organisms (Vanderploeg et al. 1996). Likewise, copepods have been shown to be 
poor grazers of Nodularia (Sellner 1997), and in the Baltic Sea they appear to actively avoid consuming toxic cyanobacteria (Karjalainen et al. 2007). Cladocerans, such as Daphnia spp., tend to be more generalist grazers than copepods (Boon et al. 1994), and it is these that are often implicated in the reduction of toxic cyanobacteria (Matveev et al. 1994). Even so, different members of the Daphnia genus have been shown to either enhance or reduce cyanobacterial growth (Fey \& Cottingham 2011), and it cannot be assumed that the presence of cladocerans would lead to a reduction in Nodularia.

In the Peel-Harvey estuary in Western Australia, winter diatom blooms are consumed by the resident zooplankton population, which then collapses with the onset of a Nodularia bloom (Lukatelich \& McComb 1986). A similar winter diatom bloom often occurs prior to a Nodularia bloom in the Gippsland Lakes (Cook et al. 2010), and the zooplankton community is likely to follow a similar pattern. We hypothesise that because Nodularia is a rare and unpredictable occurrence in the Gippsland Lakes, the grazing community is not well adapted to it and grazers capable of consuming Nodularia are either not present or are present in numbers so low as to be ineffective in controlling the onset of a bloom. Instead, grazing may facilitate a bloom by removing competitors.

The exact mechanism by which grazing stimulates Nodularia growth remains unclear. We propose that grazing of other phytoplankton taxa reduces their growth potential, while also releasing nutrients which are then available for Nodularia growth. The lack of a significant difference in the maximum growth rate of Nodularia with the addition of $\mathrm{N}$ and $\mathrm{P}$ suggests that micronutrients may have limited Nodularia growth. $\mathrm{N}_{2}$-fixing cyanobacteria require high concentrations of $\mathrm{Fe}$ and Mo for nitrogenase synthesis, and it has been hypothesised that these elements may limit cyanobacterial growth, particularly in estuaries (Howarth et al. 1988). Dissolved organic matter is another factor that has been shown to stimulate the growth of $\mathrm{N}_{2}$-fixing cyanobacteria, including Nodularia (Howarth et al. 1988, Paerl 1990, Stolte et al. 2006). Grazing may therefore stimulate the growth of Nodularia by liberating dissolved organic matter (Moller 2005) and/or metal co-factors from the phytoplankton that they consume.

\section{CONCLUSIONS}

The coupling of physico-chemical monitoring within the Gippsland Lakes with short-term bioas- says of grazing pressure and nutrient limitation provided a broad insight into the controls on the growth and bloom potential of Nodularia in this system during the summer of 2010 to 2011. Nitrogen limitation was a prerequisite for Nodularia proliferation in the bioassays, and from the in situ nutrient measurements we are confident that this was also the case within the lakes. Relatively low salinity and high temperatures were also important. Once it appeared, it is clear that the Nodularia was being minimally grazed, giving it an advantage over other phytoplankton taxa which were strongly grazed. Given that the top down (grazing) and bottom up (nutrient) pressures were strongly favouring Nodularia growth, we can conclude that the critical environmental factors limiting Nodularia growth were the in situ physical conditions, including increased wind speed and reduced solar exposure. Had the in situ weather conditions remained favourable, a bloom would have been likely.

Acknowledgements. We thank K. Brown and V. Eate for their involvement in the field and laboratory work. R. Woodland provided valuable statistical advice. This work was supported by a grant from the Gippsland Lakes and Catchment Taskforce. D.P.H. is supported by the Australian Research Council (ARC Discovery Project grant DP1095693 to J.B.).

\section{LITERATURE CITED}

Boon P, Bunn S, Green J, Shiel R (1994) Consumption of cyanobacteria by freshwater zooplankton: implications for the success of 'top-down' control of cyanobacterial blooms in Australia. Mar Freshw Res 45:875-887

> Chan F, Marino RL, Howarth RW, Pace ML (2006) Ecological constraints on planktonic nitrogen fixation in saline estuaries. II. Grazing controls on cyanobacterial population dynamics. Mar Ecol Prog Ser 309:41-53

Codd G, Steffensen D, Burch M, Baker P (1994) Toxic blooms of cyanobacteria in Lake Alexandrina, South Australia-learning from history. Mar Freshw Res 45: 731-736

> Cook PLM, Holland DP (2012) Long-term nutrient loads and chlorophyll dynamics in a large temperate Australian lagoon system affected by recurring blooms of cyanobacteria. Biogeochemistry 107:261-274

> Cook PLM, Holland DP, Longmore AR (2010) Effect of a flood event on the dynamics of phytoplankton and biogeochemistry in a large temperate Australian lagoon. Limnol Oceanogr 55:1123-1133

> Dodds WK (2003) Misuse of inorganic N and soluble reactive $\mathrm{P}$ concentrations to indicate nutrient status of surface waters. J N Am Benthol Soc 22:171-181

- Fey SB, Cottingham KL (2011) Linking biotic interactions and climate change to the success of exotic Daphnia lumholtzi. Freshw Biol 56:2196-2209

Goldberg DE, Rajaniemi T, Gurevitch J, Stewart-Oaten A (1999) Empirical approaches to quantifying interaction intensity: competition and facilitation along productivity gradients. Ecology 80:1118-1131 
Gorokhova E, Engstrom-Ost J (2009) Toxin concentration in Nodularia spumigena is modulated by mesozooplankton grazers. J Plankton Res 31:1235-1247

Hambright KD, Hairston NG, Schaffner WR, Howarth RW (2007) Grazer control of nitrogen fixation: phytoplankton taxonomic composition and ecosystem functioning. Fundam Appl Limnol 170:103-124

- Horne AJ, Galat DL (1985) Nitrogen fixation in an oligotrophic, saline desert lake: Pyramid Lake, Nevada. Limnol Oceanogr 30:1229-1239

Howarth RW, Marino R (2006) Nitrogen as the limiting nutrient for eutrophication in coastal marine ecosystems: evolving views over three decades. Limnol Oceanogr 51: 364-367

> Howarth RW, Marino R, Cole JJ (1988) Nitrogen fixation in freshwater, estuarine, and marine ecosystems. 2. Biogeochemical controls. Limnol Oceanogr 33:688-701

> Jakob T, Schreiber U, Kirchesch V, Langner U, Wilhelm C (2005) Estimation of chlorophyll content and daily primary production of the major algal groups by means of multiwavelength-excitation PAM chlorophyll fluorometry: performance and methodological limits. Photosynth Res 83:343-361

Jöhnk KD, Huisman JEF, Sharples J, Sommeijer BEN, Visser PM, Stroom JM (2008) Summer heatwaves promote blooms of harmful cyanobacteria. Glob Change Biol 14: 495-512

> Jones GJ, Blackburn SI, Parker NS (1994) A toxic bloom of Nodularia spumigena Mertens in Orielton Lagoon, Tasmania. Aust J Mar Freshw Res 45:787-800

Karjalainen M, Engstrom-Ost J, Korpinen S, Peltonen H and others (2007) Ecosystem consequences of cyanobacteria in the Northern Baltic Sea. Ambio 36:195-202

> Landry MR, Hassett RP (1982) Estimating the grazing impact of marine micro-zooplankton. Mar Biol 67: 283-288

> Lorenzen CJ (1967) Determination of chlorophyll and phaeopigments: spectrophotometric equations. Limnol Oceanogr 12:343-346

> Lukatelich RJ, McComb AJ (1986) Nutrient levels and the development of diatom and blue-green algal blooms in a shallow Australian estuary. J Plankton Res 8:597-618

> Marcarelli AM, Wurtsbaugh WA, Griset O (2006) Salinity controls phytoplankton response to nutrient enrichment in the Great Salt Lake, Utah, USA. Can J Fish Aquat Sci 63:2236-2248

Marino R, Chan F, Howarth RW, Pace M, Likens GE (2002) Ecological and biogeochemical interactions constrain planktonic nitrogen fixation in estuaries. Ecosystems 5: 719-725

> Marino R, Chan F, Howarth RW, Pace ML, Likens GE (2006) Ecological constraints on planktonic nitrogen fixation in saline estuaries. I. Nutrient and trophic controls. Mar Ecol Prog Ser 309:25-39

> Matveev V, Matveeva L, Jones G (1994) Study of the ability of Daphnia carinata King to control phytoplankton and resist cyanobacterial toxicity: implications for biomanipulation in Australia. Mar Freshw Res 45:889-904

McComb AJ, Humphries R (1992) Loss of nutrients from catchments and their ecological impacts in the Peel-

Editorial responsibility: Matthias Seaman, Oldendorf/Luhe, Germany
Harvey estuarine system, Western Australia. Estuaries 15:529-537

Moisander PH, Hench JL, Kononen K, Paerl HW (2002) Small-scale shear effects on heterocystous cyanobacteria. Limnol Oceanogr 47:108-119

Moisander PH, Steppe TF, Hall NS, Kuparinen J, Paerl HW (2003) Variability in nitrogen and phosphorus limitation for Baltic Sea phytoplankton during nitrogen-fixing cyanobacterial blooms. Mar Ecol Prog Ser 262:81-95

> Moller EF (2005) Sloppy feeding in marine copepods: preysize-dependent production of dissolved organic carbon. J Plankton Res 27:27-35

> Myers JH, Beardall J, Allinson G, Salzman S, Gunthorpe L (2010) Environmental influences on akinete germination and development in Nodularia spumigena (Cyanobacteriaceae), isolated from the Gippsland Lakes, Victoria, Australia. Hydrobiologia 649:239-247

> Myers J, Beardall J, Allinson G, Salzman S, Robertson S, Gunthorpe L (2011) Potential triggers of akinete differentiation in Nodularia spumigena (Cyanobacteriaceae) isolated from Australia. Hydrobiologia 671:165-180

> Paerl HW (1990) Physiological ecology and regulation of $\mathrm{N}_{2}$ fixation in natural waters. Adv Microb Ecol 11:305-344

Panosso R, Graneli E (2000) Effects of dissolved organic matter on the growth of Nodularia spumigena (Cyanophyceae) cultivated under $\mathrm{N}$ or P deficiency. Mar Biol 136:331-336

> Peeters JCH, Peperzak L (1990) Nutrient limitation in the North Sea: a bioassay approach. Neth J Sea Res 26:61-73

> Pollard PC, Young LM (2010) Lake viruses lyse cyanobacteria, Cylindrospermopsis raciborskii, enhances filamentous-host dispersal in Australia. Acta Oecol 36:114-119

> Reynolds CS, Walsby AE (1975) Water-blooms. Biol Rev Camb Philos Soc 50:437-481

> Sellner KG (1997) Physiology, ecology, and toxic properties of marine cyanobacteria blooms. Limnol Oceanogr 42: 1089-1104

Stal LJ, Albertano P, Bergman B, von Brockel K and others (2003) BASIC: Baltic Sea cyanobacteria. An investigation of the structure and dynamics of water blooms of cyanobacteria in the Baltic Sea - responses to a changing environment. Cont Shelf Res 23:1695-1714

Stolte W, Balode M, Carlsson P, Grzebyk D and others (2006) Stimulation of nitrogen-fixing cyanobacteria in a Baltic Sea plankton community by land-derived organic matter or iron addition. Mar Ecol Prog Ser 327:71-82

Twomey L, Thompson PF (2001) Nutrient limitation of phytoplankton in a seasonally open bar-built estuary: Wilson Inlet, Western Australia. J Phycol 37:16-29

> Vanderploeg HA, Liebig JR, Gluck AA (1996) Evaluation of different phytoplankton for supporting development of zebra mussel larvae (Dreissena polymorphya): the importance of size and polyunsaturated fatty acid content. J Gt Lakes Res 22:36-45

Webster IT, Parslow JS, Grayson RB, Molloy RP and others (2001) Gippsland Lakes environmental study: assessing options for improving water quality and ecological function. Final Report November 2001, CSIRO, Glen Osmond

Widdows J (1991) Physiological ecology of mussel larvae. Aquaculture 94:147-163

Submitted: February 20, 2012; Accepted: May 25, 2012

Proofs received from author(s): August 3, 2012 